Vesna Janković Milić ${ }^{1}$

Sonja Jovanović ${ }^{2}$

University of Niš, Faculty of Economics
ORIGINAL SCIENTIFIC ARTICLE doi:10.5937/ESD1902001J

Received: November, 10, 2019

Accepted: December, 11, 2019

\title{
SENSITIVITY ANALYSIS OF TRAVEL AND TOURISM COMPETITIVENESS INDEX TO CHANGES IN COMPONENT WEIGHTING ${ }^{3}$
}

\begin{abstract}
The competitiveness of the tourism industry in contemporary business conditions is a key factor for the success and survival on the market. In this regard, it is very important that not only companies, but also national tourism economies, monitor the level of competitiveness they have reached in order to get directive on how to further improve their business. One of the important indicators of the competitiveness of tourism at the level of national economies is the Travel and Tourism Competitiveness Index (TTCI) created by the World Economic Forum (WEF). However, there are different opinions in the literature about the methodology of this Index, especially when it comes to attributing significance to each variable that is an integral part of it. The subject of research in this paper is the methodology of the Tourism and Travel Competitiveness Index. The aim is to analyze the sensitivity of this Index to changes in the relative importance of the involved variables. The result of the research is to weight the variables within the Index and to obtain new values of subindices that determine the new, different ranking of countries on the world list according to tourism competitiveness.
\end{abstract}

Key words: tourism, competitiveness, weighting, sensitive analysis.

JEL classification: Z32, C18, O57

\section{АНАЛИЗА ОСЕТЉИВОСТИ ИНДЕКСА КОНКУРЕНТНОСТИ ТУРИЗМА И ПУТОВАЊА НА ПРОМЕНЕ У ПОНДЕРИСАЊУ ЊЕГОВИХ КОМПОНЕНТИ}

\begin{abstract}
Апстракт
Конкурентност туристичке привреде у савременим условима послована представль кльчан фактор успеха и опстанка на тржишту. У том смислу је јако важно да, не само предузећа, већ и туристичке привреде прате ниво конкурентности који су достигле, како би добили смернице за дала унапређена свог послована. Један од важних показатель конкурентности туризма на нивоу националних привреда јесте Индекс конкурентности туризма и путована, креиран од стране Светског економског форума. Међутим, у литератури постоје

\footnotetext{
${ }^{1}$ vesna.jankovic@eknfak.ni.ac.rs

${ }^{2}$ sonja.jovanovic@eknfak.ni.ac.rs

${ }^{3}$ The paper is a result of research within the project 179066, funded by the Ministry of Education, Science and Technological Development of the Republic of Serbia
} 
другачија мишльеьа о методологији овог Индекса, нарочито када је у питағу придаваюе значаја свакој варијабли која је юегов саставни део. Предмет истраживан а у овом раду јесте методологија Индекса конкурентности туризма и путована. Циљь рада јесте извршити анализу осетливости овог Индекса на промене релативног значаја укључених варијабли. Резултат истраживаюа у раду јесте пондерисате варијабли у оквиру сваког од четири подиндекса овог Индекса и добијане нових вредности подиндекса које определьуу и нови, другачији ранг земать а на светској листи према конкурентности у туризму.

Клучне речи: туризам, конкурентност, пондерисане, анализа осетљивости.

\section{Introduction}

The interest in the competitiveness of the tourism sector in terms of the dynamic and hardly predictable business environment is certainly expressed. The achieved level of competitiveness is an indicator on which the future development policies and strategies of this sector should be based. For the national economy is of particular importance to improve each segment that represents the element of competitiveness in order to be closer to the best tourist destinations. Therefore, the importance of the Travel and Tourism Competitiveness Index, as a generally accepted indicator of competitiveness of tourism of national economies, in this segment is highlighted.

However, the methodology used by the World Economic Forum to calculate this index is a matter of interest for a some authors, who also hold a critical view. One of the authors' remarks relates to giving equal importance to all the variables involved in the calculation of this Indes. The Travel and Tourism Competitiveness Index (TTCI) consists of four subindices, which are calculated as a simple average of fourteen pillars. That means that to each pillar the equal importance has been assigned. Bearing in mind the large number of complaints about the weighting pillars included in TTCI, the paper emphasizes the calculation of weights according to the relative importance of the pillars.

The aim of the research in this paper is to analyze the sensitivity of this Index to changes in the relative importance of the involved variables. The result of the research is to weight the variables within each of the four subindices of this Index and to obtain new values of subindices. The result is a new and different ranking of countries in the world according to competitiveness in tourism.

\section{Travel and Tourism Competitiveness Index and some limitations in its methodology}

The competitiveness of the tourism industry in modern conditions of globalization is a key factor for the success of tourism enterprises in the market. In addition to monitoring and investing efforts to improve the competitiveness of individual enterprise, monitoring and improving the competitiveness of tourism of each national economy is great importance in that sense, one of the generally accepted indicators of tourism competitiveness at the level of the national economy is The Travel and Tourism Competitiveness Index created by the World 
Economic Forum since 2007 (WEF, 2017, p. 50). The main objective of the methodology within the Travel and Tourism Competitiveness Index is to quantify the impact of factors and policies that affect the attractiveness and development of tourism in different countries (WEF, 2017, p. 46). Through the annual Travel \& Tourism Competitiveness Report, the World Economic Forum assesses factors that affect the competitiveness of tourism and ranks of countries according to the established Travel and Tourism Competitiveness Index (Jovanović, 2016, p. 149). The starting point of this model is that the destination competitiveness is based on inherited resources, which makes its comparative advantages, and the capacity of the destination to further develop existing resources and create competitive advantages (Crouch, 2007).

The structure of the Travel and Tourism Competitive Index (Figure 1) consists of subindices obtained as the mean of a large number of variables. The data used to calculate the value of each variable are derived from the official reports of the states covered by the Index and on the basis of the data from Executive Opinion Survey Sample. „The Survey provides a yearly evaluation of critical aspects of competitiveness for which statistical data is missing because it is either impossible or extremely difficult to measure on a global scale" (WEF, 2018).

Figure 1. Subindices of the Travel and Tourism Competitiveness Index (2015 - 2017)

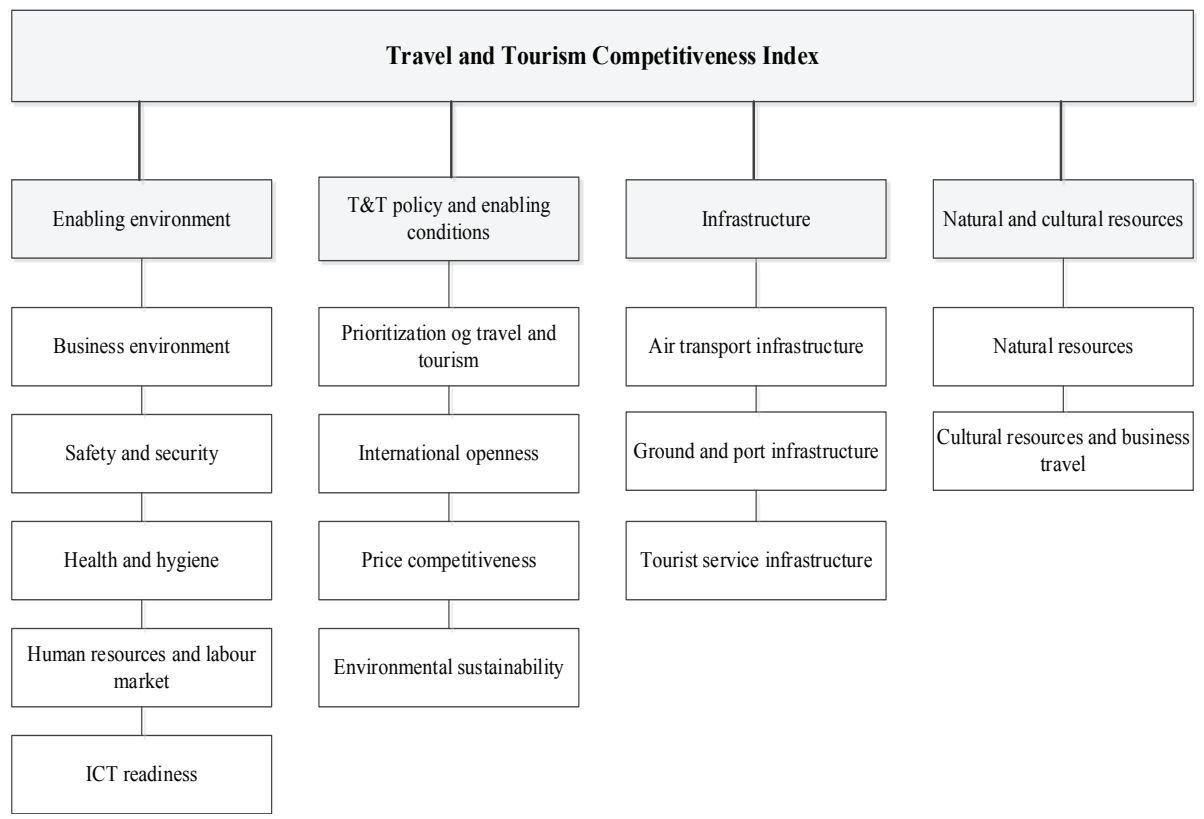

Source: WEF (2015) The Travel and Tourism Competitiveness Report 2015, Geneva, Switzerland

The Travel and Tourism Competitiveness Index now consists of four subindices (WEF, 2015, p. v). According to the Travel \& Tourism Competitiveness Report from 2015 and 2017, subindeces of this Index are (WEF, 2017, p. 4):

1. Enabling Environment. - This subindex includes five pillars: Business environment, Safety and security, Health and hygiene, Human resources and labour market and ICT readiness. 
2. T\&T Policy and Enabling Conditions. - This subindex includes four pillars: Prioritization of travel and tourism, International openness, price competitiveness and Environmental sustainability.

3. Infrastructure. - This subindex includes the level of availability and quality of physical infrastructure necessary for the development of tourism within each national economy, such as Air transport infrastructure, Ground and port infrastructure and tourist service infrastructure.

4. Natural and Cultural Resources. - The basis of this subindex constitutes two pillars: Natural resources and Cultural resources and business travel.

The methodology for calculating TTCI is often discussed by researchers (Zečević, 2011; Fernández \& Díaz, 2017; Lopes, Muñoz \& Alarcón-Urbistondo, 2018). One of the disadvantages that is often highlighted is the weighting of variables. In a large number of studies stands out the limitation of the Travel and Tourism Competitiveness Index because this model of competitiveness gives equal importance and significance to all indicators included in the analysis. However, the question arises is whether all indicators are equally significant to the tourist when deciding on the destination's choice (Lubbe, 2015) or whether a potential tourist gives some indicators a greater or lesser significance.

Thus, Crouch (2007) points to several shortcomings in the Travel and Tourism Competitiveness Index. According to him, one of the drawbacks of this Index is weighting of variables (p. 77). The Travel and Tourism Competitiveness Index does not weight the variables included in the analysis. This means that equal importance has been given to all variables.

Lin \& Huang (2009) in their research deal with the problem of weighting the variables and apply Grey Relational Analysis and sensitivity analysis ,in order to be able to evaluate the tourism competitive potential and to identify and analyse the essential criteria of tourism competitiveness in Asian countries” (p. 281).

Vega \& Picazo-Tadeo (2018) in their research „World tourist destinations with a composite indicator of competitiveness: To weigh or not to weigh?" used the Data Envelopment Analysis and Multi-Criteria-Decision-Making techniques to rank countries covered by the Tourism Competitiveness Report of the WEF according to the new weighted indicators. The conclusion to which they came is that „several economic, geographical, cultural and political features are significant determinants of the competitiveness of tourist destinations" (p. 20).

Pulido-Fernández \& Rodríguez (2016) use an alternative methodology for calculating this index based on two points of reference to propose a new standardisation, which takes the aspiration and reservation level for each pillar. Subsequently, they calculated a synthetic index that measures the state of the pillar in the worst position, as well as other alternative indices. After the analysis, they ranked the countries according to the new index values and got a different ranking compared to the Tourism Competitiveness Report issued by the WEF (Pulido-Fernández \& Rodríguez, 2012, p. 137).

Lan, Wu \& Lee (2012) in their paper „Exploring an Objective Weighting System for Travel \& Tourism Pillars" use Expectation Maximization (EM) clustering algorithm to group the 139 ranked countries into three classes and then performs the Artificial Neural Network (ANN) analysis to explore the objective weighting system for the fourteen pillars. The analysis concludes that Tourism infrastructure, Ground transport infrastructure, Air transport infrastructure, Cultural resources, Health and hygiene and ICT infrastructure are the most important pillars that influence the overall tourism competitiveness Index (Lana, Wub \& Lee, 2012, p. 189). 
TTCI calculation based on weights obtained by Principal Component Analysis

When aggregating indicators into a composite index, weights can be assigned according to the adopted theoretical framework, expert opinion, the results of factor analysis (in case of using sets of heterogeneous variables), correlation with the dependent variable (Saisana \& Tarantola, 2002). Their goal is that the weight of the weights corresponds to the relative importance of each variable (or group of variables or components) in the composite index (Greco et al., 2019). The weights have an important influence on the values of the composite indices and therefore the weighting system must be explicit and transparent.

The following weighting methods are most commonly used (Jovičić, 2006):

- Equal weights,

- Weights based on statistical models (such as regression analysis or principal component method)

- Expert opinion weights (budget allocation, analytical hierarchical process, etc.)

Each of the weighting methods has its advantages and disadvantages in terms of potentiating one and marginalizing other factors that influence the expression of the preference of the decision-makers. In this paper, the method of principal components for the determination of weights was applied. Principal component analysis (PCA) is a method within a factor analysis, which provides several possibilities for calculation of weights. The goal of PCA to extract the maximum variance from the data set with each component. The first component is a linear combination of observed variables that maximally separates subjects by maximizing the variance of their component scores. The second component is formed from residual correlations, and the subsequent components also extract maximum variability from residual correlations (Tabachnick \& Fidell, 2007).

As the TTCI consists of four subindices, created from fourteen pillars, a factor analysis was applied to each of subindices in order to obtain weights that indicate the importance of each pillar included into subindex. The first subindex Enabling environment includes five pillars: Business Environment, Safety and security, Health and Hygiene, Human resources and labour market and ICT readiness. These pillars will be the variables included in the first factor analysis. First, the fulfillment of assumptions for the application of factor analysis was checked. Based on the Kaiser-Meyer-Olkin Measurement of Sampling Adequacy value, which was higher than 0.5 (Table 2), it can be concluded that the conditions for the factor analysis application are met. Also, based on realized significance level of the Bartlett's Test of Sphericity (by which the correlation matrix was tested), it can be concluded that the data are suitable for the application of factor analysis.

Table 2. KMO and Bartlett's Test results for the first subindex

\begin{tabular}{|c|c|c|}
\hline \multicolumn{2}{|c|}{ Kaiser-Meyer-Olkin Measure of Sampling Adequacy. } & 0.784 \\
\hline \multirow{3}{*}{ Bartlett's Test of Sphericity } & Approx. Chi-Square & 470.748 \\
\cline { 2 - 3 } & Df & 10 \\
\cline { 2 - 3 } & Sig. & 0.000 \\
\hline
\end{tabular}

Source: Authors 'calculation 
Criteria for a number of factors (components) extracted were: associated eigenvalues higher than one and cumulative variance explained at least $60 \%$. According to these criteria, one component was extracted. Only one component has an eigenvalue higher than $1(3,511)$, and at the same time this component explains $70.22 \%$ of the total variability (Table 3 ). In this way, it was confirmed that the Enabling environment subindex could be expressed as a single latent variable made up of five original variables (pillars).

Table 3. The variance explained by the first factor analysis

\begin{tabular}{|c|c|c|c|}
\hline \multirow{2}{*}{ Component } & \multicolumn{3}{|c|}{ Initial Eigenvalues } \\
\cline { 2 - 4 } & Total & \% of Variance & Cumulative \% \\
\hline 1 & 3.511 & 70.225 & 70.225 \\
\hline 2 & 0.696 & 13.919 & 84.145 \\
\hline 3 & 0.474 & 9.488 & 93.633 \\
\hline 4 & 0.184 & 3.685 & 97.318 \\
\hline 5 & 0.134 & 2.682 & 100.000 \\
\hline
\end{tabular}

Source: Authors ' calculation

The level of agreement of each pillar with the subindex is expressed by factor loadings (Table 4), while the square of the factor loading represents the proportion of the total unit variance of the pillar which is explained by the subindex. Weighting is based on squared values of factor loadings ( $\%$ of the variance).

Table 4. Factor loadings and weights in the first factor analysis

\begin{tabular}{|l|c|c|c|}
\hline Pillar & $\begin{array}{c}\text { Factor } \\
\text { loading }\end{array}$ & Squared factor loading & Weight \\
\hline Business environment & 0.800 & 0.640 & 0.192 \\
\hline Safety and security & 0.740 & 0.548 & 0.177 \\
\hline Health and Hygiene & 0.786 & 0.619 & 0.188 \\
\hline Human resources and labor market & 0.918 & 0.842 & 0.220 \\
\hline ICT readiness & 0.929 & 0.863 & 0.223 \\
\hline
\end{tabular}

Source: Authors ' calculation

By analyzing the calculated values of the weights it can be noticed that the highest relative importance in the structure of the Enabling environment belongs to the ICT dimension (0.223), while the least significant pillar is Safety and security $(0,177)$. In calculating Enabling environment subindex the weighted arithmetic mean was applied (which represents a fundamental difference compared to the current methodology for TTCI score calculation).

The subject of the second factor analysis was the pillars included in the second subindex T\&T Policy and enabling condition. These are pillars: Prioritization of travel and tourism, International openness, Price competitiveness and Environmental sustainability. In this case, the preconditions for applying factor analysis were checked. Kaiser-MeyerOlkin Measure of Sampling Adequacy amounts 0,648, and significance of Bartlett's Test of Sphericity is lower than 0,0001. So it can be said that the conditions for applying factor analysis are fulfilled. According to the above mentioned criteria for factors extraction, only one component is extracted, since only one component has an eigenvalue higher than 1 (Table 5). 
Table 5. The variance explained in the second factor analysis

\begin{tabular}{|c|c|c|c|}
\hline \multirow{2}{*}{ Component } & \multicolumn{3}{|c|}{ Initial Eigenvalues } \\
\cline { 2 - 4 } & Total & \% of Variance & Cumulative \% \\
\hline 1 & 2.228 & 55.701 & 55.701 \\
\hline 2 & 0.918 & 22.959 & 78.661 \\
\hline 3 & 0.507 & 12.673 & 91.334 \\
\hline 4 & 0.347 & 8.666 & 100.000 \\
\hline \multicolumn{4}{|l}{ Extraction Method: Principal Component Analysis } \\
\hline
\end{tabular}

Source: Authors ' calculation

From the aspect of the factor analysis, subindex T\&T Policy and enabling condition can be regarded as a new latent variable which includes four empirical variables (pillars). Based on the values of factor loadings (Table 6), it can be seen that pillar Price competitiveness is inversely correlated with the subindex. Because of situations like this, the basis for calculating the weights are squared values of factor loadings.

Table 6. Factor loadings and weights in the second factor analysis

\begin{tabular}{|l|c|c|c|}
\hline Pillar & Factor loading & $\begin{array}{c}\text { Squared factor } \\
\text { loading }\end{array}$ & Weight \\
\hline Prioritization of travel and tourism & 0.723 & 0.523 & 0.235 \\
\hline International openness & 0.826 & 0.683 & 0.306 \\
\hline Price competitiveness & -0.684 & 0.468 & 0.210 \\
\hline Environmental sustainability & 0.744 & 0.554 & 0.248 \\
\hline
\end{tabular}

Source: Authors ' calculation

By analyzing the calculated values of the weights it can be noticed that the highest relative importance in the structure of T\&T Policy and enabling condition belongs to the pillar International openness (0.306), while the least significant pillar is Price competitiveness (0.210). The score of T\&T Policy and enabling condition has been calculated as the weighted average.

The subject of the third factor analysis, applied in this paper were the pillars included in the subindex named Infrastructure, which are: Air transport infrastructure, Ground and port infrastructure and Tourist service infrastructure. At the beginning, the conditions for the application of factor analysis were checked and they were fulfilled. Kaiser-Meyer-Olkin Measure of Sampling Adequacy amounts 0.747 and significance of Bartlett's Test of Sphericity is lower than 0.0001 . According to the criteria for the number of factors to be extracted. In this case only one factor has an eigenvalue higher than 1 . At the same time, $82.48 \%$ of the total variability was explained by this factor (Table 7 ).

Table 7. The variance explained in the third factor analysis

\begin{tabular}{|c|c|c|c|}
\hline \multirow{2}{*}{ Component } & \multicolumn{3}{|c|}{ Initial Eigenvalues } \\
\cline { 2 - 4 } & Total & \% of Variance & Cumulative \% \\
\hline 1 & 2.474 & 82.480 & 82.480 \\
\hline 2 & 0.293 & 9.782 & 92.261 \\
\hline 3 & 0.232 & 7.739 & 100.000 \\
\hline Extraction Method: Principal Component Analysis \\
\hline
\end{tabular}

Source: Authors ' calculation 
Table 8 shows the values of factor loadings, based on which it can be seen that the highest level of agreement with the subindex Infrastructure shows pillar Air transport infrastructure, while the lowest level of agreement shows pillar Ground and port infrastructure.

Table 8. Factor loadings and weights in the first factor analysis

\begin{tabular}{|c|c|c|c|}
\hline Pillar & Factor loading & Squared factor loading & Weight \\
\hline ATI & 0.918 & 0.843 & 0.337 \\
\hline GPI & 0.896 & 0.803 & 0.329 \\
\hline TSI & 0.910 & 0.828 & 0.334 \\
\hline
\end{tabular}

Source: Authors ' calculation

The weights calculated on the basis of squared factor loadings are quite uniform in this subindex. The pillar Air transport infrastructure has a slightly higher weight than the other two pillars (0.377), while the pillar Ground and port infrastructure has the lowest weighting value (0.329). The score of subindex Infrastructure was calculated as the weighted mean of the three pillars listed.

The fourth subindex within the TTCI called Natural and Cultural Resources and consists of two pillars: Natural Resources and Cultural Resources and Business Travel. Factor analysis was also applied to these pillars. Factor loadings and weights based on them indicate the equal importance of these two pillars in the subindex structure. So, the procedure for calculating the values of the Natural and Cultural resources subindex has not been altered in relation to the current WEF methodology. The overall score of TTCI was calculated as the simple mean of the four subindices, which provides the equal importance of all these composite indicators of tourism competitiveness.

Table 8 shows a comparative overview of the descriptive measures for the TTCI score according to the current methodology (applied in reports) and according to the proposed methodology. Based on descriptive measures, it can be concluded that the change in the TTCI calculation methodology would change the min and max values of the TTCI, as well as the average TTCI values from 3.821 to 3.786 (Table 9). However, the variability is higher. Namely, according to the new methodology, the average deviation of each country's score from the average TTCI score is 0.704 , which is higher than the deviation according to the current methodology.

Table 9. Descriptive statistics

\begin{tabular}{|l|c|c|c|c|}
\hline Variable & Mean & $\mathrm{N}$ & Std. Deviation & Std. Error Mean \\
\hline TTCI - report & 3.821 & 136 & 0.686 & 0.059 \\
\hline TTCI -new methodology & 3.784 & 136 & 0.704 & 0.060 \\
\hline
\end{tabular}

Source: Authors ' calculation

Paired samples t-test was applied in order to test the significance of differences in the average values of TTCI according to the current and new methodology. A decrease in the average TTCI value of 0.037 after the application of the new methodology was found to be statistically significant ( $\mathrm{p}$-value $<0.001$ ). This means that changing the methodology 
significantly influences the average measured level of competitiveness in the tourism of analyzed countries (Table 10).

Table 10. Results of paired samples t-test

\begin{tabular}{|c|c|c|c|c|c|c|c|c|}
\hline & \multicolumn{5}{|c|}{ Paired Differences } & \multirow{3}{*}{$\mathrm{t}$} & \multirow{3}{*}{ df } & \multirow{3}{*}{$\begin{array}{c}\text { Sig. } \\
\text { (2-tailed) }\end{array}$} \\
\hline & \multirow[t]{2}{*}{ Mean } & \multirow[t]{2}{*}{$\begin{array}{c}\text { Std. } \\
\text { Deviation }\end{array}$} & \multirow{2}{*}{$\begin{array}{l}\text { Std. } \\
\text { Error } \\
\text { Mean }\end{array}$} & \multicolumn{2}{|c|}{$\begin{array}{l}95 \% \text { Confidence } \\
\text { Interval of the } \\
\text { Difference }\end{array}$} & & & \\
\hline & & & & Lower & Upper & & & \\
\hline $\begin{array}{l}\text { TTCI - rep TTCI - } \\
\text { new }\end{array}$ & 0.037 & 0.115 & 0.010 & 0.018 & 0.057 & 3.798 & 135 & 0.000 \\
\hline
\end{tabular}

Source: Authors ' calculation

The change in methodology results in a change in the rank of countries for which TTCI is accounted for. Firstly, an overview of the changes in the top 10 positions in the ranking list is given in Table 11. Spain, which was the first in the rank list, remained in the first place. Germany and France switched places, as did Australia and USA.

Table 11. Top 10 countries according to both methodologies

\begin{tabular}{|c|c|c|c|c|}
\hline \multirow{2}{*}{ Rank } & \multicolumn{2}{|c|}{ According to TTCI report } & \multicolumn{2}{c|}{ According to new methodology } \\
\cline { 2 - 5 } & Country & Score & Country & Score \\
\hline & Spain & 5.4 & Spain & 5.4 \\
\hline & France & 5.3 & Germany & 5.38 \\
\hline & Germany & 5.3 & France & 5.3 \\
\hline & Japan & 5.3 & Japan & 5.24 \\
\hline & UK & 5.2 & UK & 5.22 \\
\hline & USA & 5.1 & Australia & 5.12 \\
\hline & Australia & 5.1 & USA & 5.11 \\
\hline & Italy & 5 & Italy & 5 \\
\hline & Canada & 5 & Canada & 4.96 \\
\hline & Switzerland & 4.9 & Switzerland & 4.94 \\
\hline
\end{tabular}

\section{Source: Authors ' calculation}

Changing the methodology would result in an increase in scores in a large number of countries. The biggest positive change, i.e. the largest score increase recorded Congo $(+0.18)$. The ten countries with the largest increase in TTCI score are shown in Table 12.

Table 12. Countries with the highest positive change

\begin{tabular}{|c|c|}
\hline Country & Change \\
\hline Congo & 0.18 \\
\hline Germany & 0.08 \\
\hline Colombia & 0.05 \\
\hline Denmark & 0.05 \\
\hline Peru & 0.05 \\
\hline Netherland & 0.04 \\
\hline
\end{tabular}




\begin{tabular}{|c|c|}
\hline Switzerland & 0.04 \\
\hline Belgium & 0.03 \\
\hline Israel & 0.03 \\
\hline Norway & 0.03 \\
\hline Turkey & 0.03 \\
\hline
\end{tabular}

Source: Authors ' calculation

In addition to positive changes, the revised methodology would also result in negative changes in TTCI scores, i.e. decrease in TTCI score. The largest decrease in TTCI score would be related to Mauritania (Table 13), where it would decrease by 1.3 which is as much as a decrease of $30 \%$ of the current score.

Table 13. Countries with the biggest negative change

\begin{tabular}{|c|c|}
\hline Country & Change \\
\hline Mauritania & -1.30 \\
\hline Algeria & -0.10 \\
\hline Burundi & -0.10 \\
\hline Paraguay & -0.10 \\
\hline Russia & -0.10 \\
\hline Tanzania & -0.10 \\
\hline Albania & -0.09 \\
\hline Gabon & -0.09 \\
\hline Qatar & -0.09 \\
\hline
\end{tabular}

Source: Authors ' calculation

Several countries would not change their existing score by a new methodology. Those countries are: Bosnia and Herzegovina, Croatia, Dominican Republic, Egypt, Estonia, France, Greece, Italy, Jamaica, Jordan, Senegal and Spain.

\section{Conclusion}

The Travel and Tourism Competitiveness Index consists of four subindices, wich are calculated as a simple average of fourteen pillars. That means that to each pillar the equal importance has been assigned. Bearing in mind the large number of complaints about the weighting pillars included in TTCI, the paper emphasizes the calculation of weights according to the relative importance of the pillars.

The authors use different analyzes to get new, weighted values of pillars and subidexes and thus determine which indicator within the Index contributes more or less to its total value. So, some authors use the Grey Relational Analysis, Multi-CriteriaDecision-Making techniques, and clustering. In this paper, the method of principal components for the determination of weights was applied. A factor analysis was applied to each of subindices in order to obtain weights that indicate the importance of each pillar included into subindex.

By analyzing the calculated values of the weights it can be noticed that the highest relative importance in the structure of the subindex - Enabling environment belongs to the ICT dimension, while the least significant pillar is Safety and security $(0,177)$. In the structure of subindex - T\&T Policy and enabling condition, it can be noticed that the highest relative 
importance belongs to the pillar International openness, while the least significant pillar is Price competitiveness. Within a subindex Infrastructure, the pillar Air transport infrastructure has a slightly higher weight than the other pillars, while the pillar Ground and port infrastructure has the lowest weighting value. Applied Factor analysis on forth subindex Natural and Cultural Resources indicated the equal importance of two pillars (Natural Resources and Cultural Resources) in the subindex structure.

The change in methodology in this way, results in a change in the rank of countries for which TTCI is accounted for. So, changing the methodology resulted in an increase in scores in a large number of countries. The biggest positive change, i.e. the largest score increase recorded Congo $(+0.18)$. In addition to positive changes, the revised methodology also resulted in negative changes in TTCI scores, i.e. decrease in TTCI score. The largest decrease in TTCI score be related to Mauritania. Several countries have not changed their existing score by a new methodology. Those countries are: Bosnia and Herzegovina, Croatia, Dominican Republic, Egypt, Estonia, France, Greece, Italy, Jamaica, Jordan, Senegal and Spain.

The application of different methods for assigning weights to the variables included in the TTCI can contribute to a better understanding of the importance of individual variables to the overall competitiveness. In this regard, the paper shows that TTCI is sensitive to the weighting of variables and leads to a change in the value of the subindices and the overall rankings that some countries have on the world tourism competitiveness list. This can be a useful tool for policy makers in analyzing indicators that contribute to the competitiveness of tourism at the national economy level.

\section{References}

Crouch, G. (2007). Measuring tourism competitiveness: Research, theory and the WEF index, Australian and New Zealand Marketing Academy (ANZMAC) Conference Proceedings, https://www.anzmac.org/conference_archive/2007/papers/Crouch_1. pdf (15.04.2019)

Greco, S., Ishizaka, A., Tasiou, M., \& Torrisi, G. (2019) On the Methodological Framework of Composite Indices: A Review of the Issues of Weighting, Aggregation, and Robustness. Social Indicators Research. 141(1), 61-94. DOI:10.1007/s11205-017-1832-9.

Jovanović, S. (2016). Analiza konkurentnosti sektora turizma i agrara u Republici Srbiji u periodu 2010-2015. godine sa predlogom mera za unapređenje, in Krstić, B. (ed.), Unapređenje konkurentnosti Republike Srbije, University of Niš, Faculty of Economics.

Jovičić, M. (2006) Kompozitni indeks - Magistrala multikriterijumske analize. Ekonomski anali, 171, 171-184.

Lan, L. W., Wu, W. W., \& Lee, Y. T. (2012). Exploring an Objective Weighting System for Travel \& Tourism Pillars. International Conference on Asia Pacific Business Innovation and Technology Management. Procedia - Social and Behavioral Sciences, 57, 183 - 192. DOI: 10.1016/j.sbspro.2012.09.1173 
Lin, C. T., \& Huang, Y. L. (2009). Tourism Competitiveness Evaluation in Asian Countries Applying GRA and Sensitivity Analysis. Journal of Grey System, 21 (3), 269-278.

Lopes, A. P. F., Muñoz, M. M., \& Alarcón-Urbistondo, P. (2018). Regional tourism competitiveness using the PROMETHEE approach. Annals of Tourism Research, 73, 1-13. https://doi.org/10.1016/j.annals.2018.07.003.

Lubbe, B. (2015) Is the WEF's Travel and Tourism Competitiveness Index the best benchmark?, Southern African Tourism Update, http://www.tourismupdate.co.za/ article/102027/Is-the-WEF-s-Travel-and-Tourism-Competitiveness-Index-the-bestbenchmark (10.04.2019)

Pulido-Fernández, J. \& Rodríguez, B. (2016). Reinterpreting the World Economic Forum's global tourism competitiveness index. Tourism Management Perspectives. 20, 131-140. https://doi.org/10.1016/j.tmp.2016.08.001.

Redžić, D. (2018). Significance of quality in the tourism industry: Research study on the perception of stakeholders in tourism. Menadžment u hotelijerstvu $i$ turizmu, 6(2), 11-20.

Saisana, M., \& Tarantola, S. (2002). State-of-the-art report on current methodologies and practices for composite indicator development. European Commission, Joint Research Centre, Institute for the Protection and the Security of the Citizen, Technological and Economic Risk Management Unit, Ispra, Italy. Research (PDF Available) July 2016 with 1,327 Reads. DOI: 10.13140/RG.2.1.1505.1762.

Tabachnick, B., \& Fidell, L. (2007). Using Multivariate Statistics, Pearson Education, Inc.

Vega, M. G., \& Picazo-Tadeo, A. J. (2018). World tourist destinations with a composite indicator of competitiveness: To weigh or not to weigh? Tourism Management. 72, 281-291. DOI: 10.1016/j.tourman.2018.11.006.

WEF (2015) The Travel and Tourism Competitiveness Report 2017, Geneva, Switzerland.

WEF (2017) Travel \& Tourism Competitiveness Report 2017, Geneva, Switzerland.

WEF (2018) Appendix B: The Executive Opinion Survey: The Voice of the Business Community, http://reports.weforum.org/global-competitiveness-report-2018/ appendix-b-the-executive-opinion-survey-the-voice-of-the-business-community/ (15.04.2019)

Zečević, B. (2011). Koncepti konkurentnosti turističkih destinacija: značaj i primenjivost na slučaju Srbije, Naučni skup: Novi metodi menadžmenta i marketinga u podizanju konkurentnosti srpske privrede, Naučno društvo ekonomista Srbije, Ekonomski fakultet Beograd i Ekonomski fakultet Subotica, 15. oktobar 2011, Palić. 